\title{
GENDER-RELATED DIFFERENCES IN CLINICAL COURSE OF CROHN'S DISEASE IN AN ASIAN POPULATION: a retrospective cohort review
}

\author{
Siu-tong LAW and Kin Kong LI
}

\begin{abstract}
Context - Data from Asian populations about gender-related differences in Crohn's disease are few. Objective - This study was to analyze the clinical characteristics between women and men affected by Crohn's disease. Methods - This was a retrospective cohort study to analyze consecutive Crohn's disease patients from Jan 2000 to Dec 2012. Clinical and phenotypic characteristics and treatment outcomes were evaluated. Results - 79 patients (55 male and two of them with positive family history) were diagnosed with Crohn's disease. Ileocolonic disease and inflammatory lesion was the most dominant site of involvement and disease behavior respectively in both men and women. Apart from higher frequency of nausea (45.83 vs $23.64 \%, P 0.024)$ and lower body mass index $\left(19.44 \mathrm{vs} 22.03 \mathrm{~kg} / \mathrm{m}^{2}, P 0.003\right)$ reported in women, no significant gender-related differences in clinical characteristics were observed. Women were more associated with delay use of immunosuppressive therapy (12 vs 36 months, $P=0.028$ ), particularly for those aged less than 40 years old ( 85 vs $62.6 \%, P=0.023$ ). Cox proportional hazard regression analysis revealed that active smoking (HR, 4.679; 95\% CI, 1.03-21.18) and delayed use of immunosuppressive therapy (HR, 4.13; 95\% CI, 1.01-16.88) were only independent risk factors associated with increased risk of complications. Conclusions - There were no significant gender-specific differences in clinical and phenotypic characteristics between male and female Crohn's disease patients. Smoking history and delay use of immunosuppressive therapy were associated with higher risk of complications.
\end{abstract}

HEADINGS - Crohn disease. Gender identity. Immunosuppressive agents, therapeutic use. Smoking.

\section{INTRODUCTION}

Crohn's disease (CD) is a chronic inflammatory bowel disease characterized by transmural granulomatous inflammation that can affect any part of the gastrointestinal (GI) tract. Information regarding gender-related differences in CD is relatively scarce and conflicting. Firstly, the majority of studies from the West have shown an relatively equal gender distribution for $\mathrm{CD}$, with slightly preferentially affecting women as the overall female incidence rate appeared to be about 1.5 times higher than in $\operatorname{men}^{(7,19,20,28,33,37,40)}$. In contrast, most studies in Asia have demonstrated a male predominance for $\mathrm{CD}^{(28)}$. Secondly, little information, particularly from Asian population, is available on the expression and natural history of $\mathrm{CD}$ in relation to gender. The studying of gender difference in any disease is of great importance for the recognition of factors contributing to the disease expression and governing its prognosis so that clinicians can offer appropriate medical therapy promptly. The aim of this study was to evaluate the differences in phenotypes according to the Montreal classification, clinical course and long term prognosis between female and male patients with $\mathrm{CD}$.

\section{METHODS}

\section{Patient population}

Regarding the fact that Tuen Mun Hospital (TMH) was the only hospital in the district, it served about a 1,000,000 patient population and acted as both a primary health care and tertiary referral centre. Generally, patients with suspected inflammatory bowel diseases would be referred to the gastrointestinal (GI) clinic of Department of Medicine and Geriatrics of TMH for further workup and management. From Jan 2000 to Dec 2012, there were 79 consecutive patients newly diagnosed with CD treated in TMH. The

Declared conflict of interest of all authors: none

Source of Funding: no funding has been received for the research

Authors' contributions: STL and KKL were responsible for the patient care. STL was also responsible for the conception and writing of the manuscript. All authors read and approved the final manuscript.

Division of Gastroenterology and Hepatology, Department of Medicine and Geriatrics

Tuen Mun Hospital, Tuen Mun, Hong Kong, China.

Correspondence: Dr Siu-tong Law. E-mail: st1168@hotmail.com KKLi:kk|@hotmail.com 
diagnosis of CD was based on the criteria of Lennard-Jones, which include the clinical, ileocolonoscopic, histopathologic, and radiologic findings ${ }^{(22)}$. Single-balloon enteroscopy, capsule endoscopy, fluoroscopy or both was performed when disease of the small intestine was suspected. The classification of $C D$ was made according to the Montreal classification ${ }^{(31)}$. Throughout this study, the disease location was determined at diagnosis and its behavior was categorized during followup. Information for calculating Crohn's disease activity index (CDAI) was collected at all clinic visits and input into a homemade electronic calculator to compute CDAI score.

\section{Data collection}

The study protocol was approved by the ethics board of $\mathrm{TMH}$.

Clinical information was collected with regard to the following areas:

(i) Demographic characteristics including gender, smoking habits and body mass index(BMI) on presentation;

(ii) Clinical symptoms and significant findings on physical examination on initial presentation;

(iii) Prescription of 5-aminosalicylic acid compounds, immunosuppressive (IS) agents (6-mercaptopurine, azathioprine, and methotrexate), and biologics such as monoclonal antibody against tumor necrosis factor $\alpha($ anti-TNF $-\alpha)$;

(iv) Complications during the disease course, namely severe gastrointestinal bleeding, bowel stricturing and perforation, abdominal abscess and entero-enteric fistula due to the penetrating inflammation of the bowel wall;

(v) Surgical intervention.

\section{Statistical analysis}

The data were compiled and analyzed by use of the commercial Statistical Package for the Social Sciences (SPSS) for Window (version 17.0; SPSS Inc, Chicago, IL). All continu- ous variables were expressed as median and interquartile range (IQR). Categorical variables were reported as percent. The $\chi^{2}$ test, Fisher's exact test and Mann-Whitney U test were used when appropriate. The Kaplan-Meier method was used to estimate the cumulative risk of complications, surgical intervention during the disease course and use of IS therapy of the two groups of patients, and the log-rank test was used to test for statistical significance. Multivariate Cox proportional hazards regression analysis was performed to identify independent risk factors for development of complications. Effects of potential risk factors (namely gender, smoking history, ileocolonic (L3) disease location, upper gastrointestinal tract (L4) involvement, presence of peri-anal disease, delayed use (defined as $\geq 12$ months)of immunosuppressive therapy and requirement of surgical intervention on initial presentation) were quantified by calculating the hazard ratio (HR) and confidence interval (CI) from the final Cox model. A $P$ value less than.05 was considered statistically significant.

\section{RESULTS}

\section{Demographic and clinical characteristics}

From January 2000 to December 2012 inclusive, 79 patients (55 male in which 2 of them had positive family history) were diagnosed with $\mathrm{CD}$ in $\mathrm{TMH}$, with a median follow-up of 6 years (IQR, 6 years) that had no statistically significant difference between men and women (5 year (IQR, 6 years) vs 9 years (IQR 9.75 years), $P=0.059$ ). The median age of onset of CD were similar in men (25 year, IQR 20 years) and women (28 year, IQR 23.75 years); and there was also no significant difference in the duration of $\mathrm{CD}$ between the two groups (men, 5 years, (IQR 6 years); women, 9 years (IQR 9.75 years), $P=0.059$ ). As shown in Figure 1, there was a predominance for men over women, particularly the second and third decade of life; and its extent gradually reduced in later age. The duration of symptoms before presentation did not differ between the

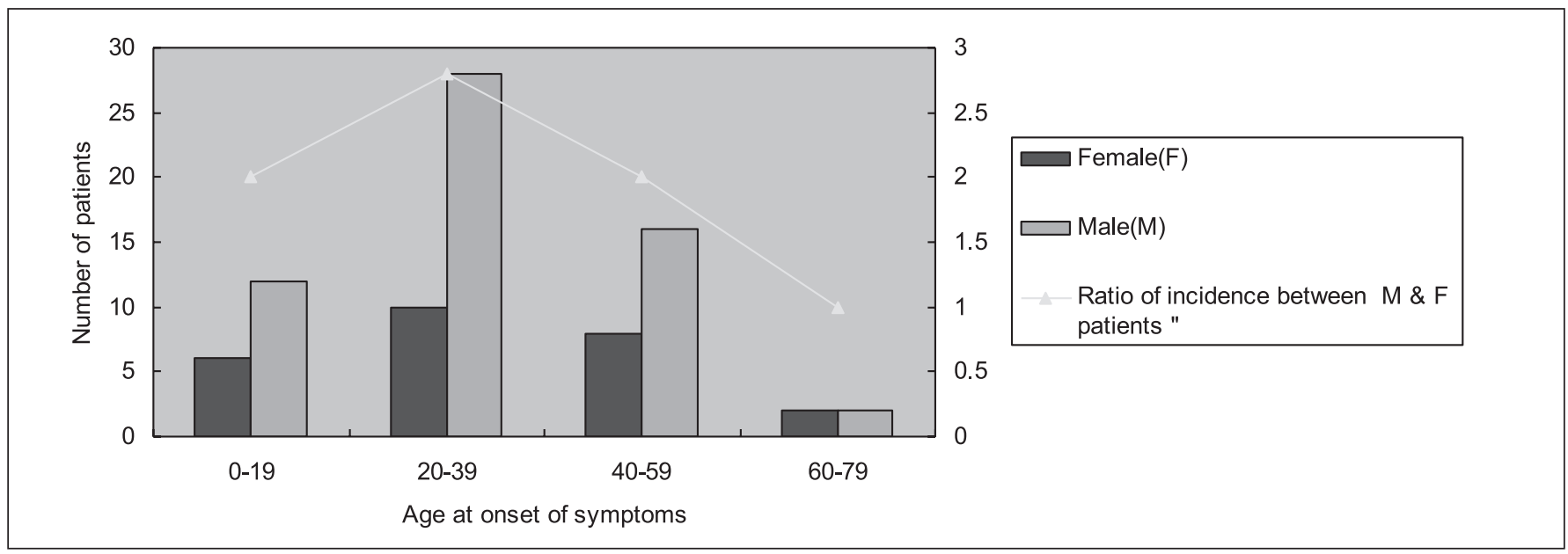

FIGURE 1 . The incidence distribution of patients with Crohn's diseases according to age and gender 
two groups (12 week (IQR 22) in men and 12 week (IQR 21.5 ) in women respectively). In Table 1 , men tended to have smoking history whereas women were significantly associated with lower BMI $\left(19.44 \mathrm{~kg} / \mathrm{m}^{2}\right.$ vs $22.03 \mathrm{~kg} / \mathrm{m}^{2}$, $P=0.003)$ on presentation. Apart from the higher frequency of nausea in the female group ( $45.83 \%$ vs $23.64 \%, P=0.024$ ), the other CD-related symptoms at presentation, such as abdominal pain $(85.45 \%$ vs $79.17 \%)$, peri-rectal bleeding $(52.73 \%$ vs $33.33 \%)$, diarrhea $(49.09 \%$ vs $58.33 \%)$, weight loss (38.18\% vs $37.50 \%)$ occurred equally frequently in men and women. Regarding extra-intestinal manifestations, they tended to be more frequently seen in women than

TABLE 1. Demographic, clinico-phenotypic characteristics and clinical course of patients with Crohn's disease

\begin{tabular}{|c|c|c|c|}
\hline Variable & Male $(n=55)$ & Female $(n=24)$ & $P$ value \\
\hline Age, yrs, median (IQR) & $25(20.0)$ & $28(23.75)$ & 0.436 \\
\hline Smoking history $(\mathrm{n}, \%)$ & $16(29.1)$ & $3(12.5)$ & 0.056 \\
\hline Comorbidities $(\mathrm{n}, \%)$ & $12(21.82)$ & $5(20.83)$ & 0.224 \\
\hline Hypertension & 3 & 3 & \\
\hline Depression & 4 & 3 & \\
\hline Others & $8^{1}$ & $2^{2}$ & \\
\hline Body mass index $\left(\mathrm{kg} / \mathrm{m}^{2}\right)$ & $22.03(3.4)$ & $19.44(6.7)$ & 0.003 \\
\hline Duration of symptoms, week & $12(22.0)$ & $12(21.5)$ & 0.961 \\
\hline Acute $^{3}$ mode of presentation $(\mathrm{n}, \%)$ & $17(30.91)$ & $7(29.17)$ & 0.436 \\
\hline \multicolumn{4}{|l|}{ Presenting symptoms } \\
\hline Nausea & $13(23.64 \%)$ & $11(45.83 \%)$ & 0.024 \\
\hline Abdominal pain ${ }^{4}$ & $47(85.45 \%)$ & $19(79.17 \%)$ & 0.245 \\
\hline Peri-rectal bleeding ${ }^{5}$ & $29(52.73 \%)$ & $8(33.33 \%)$ & 0.056 \\
\hline Diarrhoea & $27(49.09 \%)$ & $14(58.33 \%)$ & 0.224 \\
\hline \multicolumn{4}{|l|}{ Extra-intestinal manifestation } \\
\hline Oral aphthous ulcers/stomatitis & $12(21.82 \%)$ & $8(33.33 \%)$ & 0.140 \\
\hline Polyarthralgia & $6(10.91 \%)$ & $5(20.83 \%)$ & 0.121 \\
\hline Others & $2(3.64 \%)^{6}$ & $3(12.50 \%)^{7}$ & 0.067 \\
\hline Radiological features (n,\%) & $17(30.91 \%)$ & $4(16.67 \%)$ & 0.09 \\
\hline Right lower quadrate mass & 9 & 1 & \\
\hline Bowel perforation & 3 & 0 & \\
\hline Intestinal obstruction & 5 & 3 & \\
\hline \multicolumn{4}{|l|}{ Phenotypic characteristics ${ }^{8}$} \\
\hline \multicolumn{4}{|l|}{ Age at diagnosis } \\
\hline A1: 16 years old & $8(14.5 \%)$ & $2(8.30 \%)$ & 0.224 \\
\hline A2: $17-40$ years old & $34(61.80 \%)$ & $14(58.30 \%)$ & 0.386 \\
\hline A3: > 40 years old & $13(23.60 \%)$ & $18(33.33 \%)$ & 0.209 \\
\hline \multicolumn{4}{|l|}{ Disease location } \\
\hline L1: ileal & $8(14.5 \%)$ & $4(16.7 \%)$ & 0.401 \\
\hline L2: colonic & $18(32.7 \%)$ & $8(33.3 \%)$ & 0.480 \\
\hline L3: ileocolonic & $27(49.1 \%)$ & $11(45.8 \%)$ & 0.394 \\
\hline L49:upper GI & $6(10.9 \%)$ & $4(16.7 \%)$ & 0.239 \\
\hline \multicolumn{4}{|l|}{ Disease behavior } \\
\hline B1: inflammatory & $31(56.4 \%)$ & $15(62.5 \%)$ & 0.305 \\
\hline B2: stricturing & $7(12.7 \%)$ & $4(16.7 \%)$ & 0.319 \\
\hline B3: penetrating & $17(30.9 \%)$ & $5(20.8 \%)$ & 0.179 \\
\hline Perianal lesions & $20(36.36 \%)$ & $8(33.33 \%)$ & 0.397 \\
\hline fistula/abscess & $15 / 5$ & $3 / 3$ & \\
\hline Complications & $26(47.27 \%)$ & $6(25 \%)$ & 0.03 \\
\hline Bowel stricture & 16 & 8 & \\
\hline Bowel perforation & 4 & 1 & \\
\hline Others & $8^{10}$ & $3^{11}$ & \\
\hline
\end{tabular}

Data are either median (interquartile range - IQR) or no. (\%) of patients, unless otherwise indicated. Boldface type indicates statistical significance.

1. hyperlipidemia $(\mathrm{n}=3)$, viral hepatitis carrier $(\mathrm{n}=3)$, asthma $(\mathrm{n}=1)$, diabetes $(\mathrm{n}=1)$

2. asthma $(\mathrm{n}=1)$, diabetes $(\mathrm{n}=1)$

3. 7 days

4. right lower quadrate guarding tenderness with rebound: $\mathrm{n}=6$ (male), 2 (female)

5. hemodynamic instability: $\mathrm{n}=3$ (male), 1 (female)

6. pyoderma gangrenousm $(\mathrm{n}=1)$, uveitis $(\mathrm{n}=1)$

7. erythema nodosum $(n=1)$, uveitis $(n=1)$, primary sclerosing cholangitis $(n=1)$

8. categorized according to Montreal classifications

9. isolated L4: $\mathrm{n}=2$ (male), 1 (female)

10. Right lower quadrant abscess $(n=3)$, severe gastrointestinal $(G I)$ bleeding $(n=2)$, colonic carcinoma $(n=2)$, entero-enteric fistula ( $n=1)$

11. pelvic abscess $(n=1)$, severe GI bleeding $(n=1)$, entero-enteric fistula $(n=1)$ 
men whereas radiological abnormalities seemed to be more frequently encountered, particularly right lower quadrate mass lesions, in men during the imaging studies. After investigations, acute appendicitis as an incorrect preliminary diagnosis tended to be made in men, $12(12.73 \%)$ vs 1 $(4.17 \%)$ in women, data not shown. According to Montreal classification, there were no gender-specific difference in age of presentation, disease location and behavior.

\section{Treatment and clinical outcome}

Overall three-fourth of our patients had taken IS agent as maintenance therapy to control disease activity, with figure slightly higher in men $(80 \%$ vs $70.83 \%, P=0.187)$; while only eight (overall six men: two subjects used for maintenance therapy while the others used for rescue therapy for active disease activity) patients had history of anti-TNF- $\alpha$ exposure during the management of $\mathrm{CD}$.

There were two major differences in use of IS therapy between men and women. Firstly, more men were treated with IS therapy after the diagnosis of $\mathrm{CD}$ as compared with women ( 47.3 vs $16.7 \%, P=0.005)$ while women took considerably longer period of time to commence IS therapy as compared with men ( 12 month vs 36 month, $P=0.028$ ). With respect to age-specific prescription rate, women aged less than 40 years old were significant less likely to be treated with IS therapy as compared with men (36 (85\%) vs $10(62.6 \%)$, $P=0.023)$. Secondly, as compared with men, women were more prone to experience side effects of IS therapy (54.54\% vs $9.09 \%, P=0.000)$. Six events were reported in the female group in which all were related to use of azathioprine (AZA) and they were as follows: two with reversible bone marrow suppression, one each in nonspecific dizziness, allergic cutaneous rashes, herpes zoster infection and drug-induced hepatitis. Among four events reported in the male group, three of them were AZA-induced reversible bone marrow suppression and the other was Pneumocystis pneumonia due to use of methrotexate.

As shown in Table 1, more male patients experienced complicated clinical course as compared with female (26 (47.27\%) vs $6(25 \%), P=0.03)$. In addition, men seemed to develop complication early than women (48 month (IQR 72) vs 60 month (IQR 169.5), $P=0.316$ ) but Kaplan-Meier analysis revealed that there was no significant difference between the two groups (log rank test, $P=0.18$; data not shown). Of the twenty four $(30.38 \% ; 25.45 \%$ and $41.67 \%$ in men and women respectively) patients with bowel resection during the study period, more female patients $(37.5 \%$ vs. $16.4 \%, P=0.020)$ underwent exploratory laparotomies with the objective of obtaining information at presentation and thus they were less likely required to undergo surgical intervention during the disease course as compared with men $(1(4.17 \%)$ vs 5 $(9.1 \%), P=0.224)$.

After eliminating effect of confounding variables, Cox proportional hazard regression analysis revealed that active smoking and delayed use of IS therapy were the only independent risk factors associated with increased risk of complications (Table 2).
TABLE 2. Multivariate Cox regression analysis of clinical factors associated with complications in patient with Crohn's diseases

\begin{tabular}{|c|c|c|}
\hline Variable & $\begin{array}{l}\text { Hazard ratio ( } 95 \% \\
\text { confidence interval) }\end{array}$ & $P$ value \\
\hline Male sex & $1.134(0.315,4.085)$ & 0.848 \\
\hline Smoking history & $4.679(1.034,21.175)$ & 0.045 \\
\hline $\begin{array}{l}\text { Ileocolonic (L3) disease } \\
\text { location }\end{array}$ & $1.277(0.423,3.858)$ & 0.664 \\
\hline $\begin{array}{l}\text { Upper gastrointestinal } \\
\text { tract (L4) involvement }\end{array}$ & $0.633(0.191,2.101)$ & 0.455 \\
\hline Presence of perianal disease & $0.581(0.218,1.546)$ & 0.478 \\
\hline $\begin{array}{l}\text { Delayed use of } \\
\text { immunosuppressive } \\
\text { therapy * }\end{array}$ & $4.129(1.01,16.880)$ & 0.048 \\
\hline $\begin{array}{l}\text { Surgery on initial } \\
\text { presentation }\end{array}$ & $1.022(0.225,4.639)$ & 0.978 \\
\hline
\end{tabular}

* Defined as $\geq 12$ months

Boldface type indicates statistical significance

\section{DISCUSSION}

Though there are several population-based cohort studies of $\mathrm{CD}$ in Asia, data on differences in the clinical presentation and long term outcomes related to gender has not been reported. Most information in literature came from the western studies. The current study is the first retrospective study to focus on the effect of gender on the clinical course of $\mathrm{CD}$ in a Chinese population and thus it could enable us to have better understanding of sex-related difference of natural course of $\mathrm{CD}$ in order to provide better clinical care. Despite the fact that the current report was based on a single centre, residents in the district has a median household income below the average in the city and TMH itself is the only public hospital to provide the subsidized health-care service in the district and thus the data in this cohort could add information to the growing body of knowledge in the Asian population.

Congruent with previous Asian studies, including data from China ${ }^{(14,16,24,46)}$ Japan $^{(2,15,27,43)}$, Korea ${ }^{(42,44)}$, Singapore ${ }^{(21)}$, India ${ }^{(9)}$ and Sri Lanka ${ }^{(35)}$, our observation have demonstrated a male predominance in $\mathrm{CD}$, which is discordant with majority of the western studies. Such discrepancy may be sex-related differences in triggering or predisposing factors of $\mathrm{CD}$ between Asian and Western populations. The peak incidence of $\mathrm{CD}$ of both genders in our cohort was in the second and third decades of life, which is in accord with that in North American CD patients ${ }^{(23)}$. But, the feature of bimodal distribution of the age at presentation appeared in the previous western study by Farrokhyar et al. was not observed in either sex in our cohort, which is in concordant to another previous Chinese study ${ }^{(12,16)} \mathrm{CD}$ has a predilection to affect young persons, which accounts the fact that the patients of our cohort had low prevalence of comorbidities. Apparently more male patients had a positive smoking history, that was in line with our general population and such gender-related differential rates of smoking might result in 
the male predominance of $\mathrm{CD}$ in our series. The lengthy duration of presenting symptoms in both groups was related to low awareness of CD in the public. Such a poor awareness of the illness was further illustrated by considerable number of patients of both groups presented acutely, such as severe lower GI bleeding, peritonitis and intestinal obstruction. There were no significant differences in either sex regarding the most prominent $\mathrm{CD}$-related presenting symptoms such as abdominal pain, diarrhea, peri-rectal bleeding and weight loss, coincident with a previous western study ${ }^{(39)}$. Higher frequency of nausea in the female group might account the sex-related difference of BMI at presentation. Extraintestinal manifestations of $\mathrm{CD}$ represent a systemic aspect of the disease. Previous studies demonstrated that between $17 \%$ and $36 \%$ of CD patients will have at least one such disease associated symptom ${ }^{(11,13,29)}$, in which certain groups of manifestations are associated with the intestinal disease activity and can be managed by the IS therapy. In the present study, the reported frequency of extra-intestinal manifestation in the female group tended to be higher than that in the male, which is in accord to recent epidemiological data ${ }^{(38,39)}$. The disease localization and phenotypic behavior at time of diagnosis did not differ between both sexes in our cohort, which is in accord with the above-mentioned study ${ }^{(39)}$. Congruent with the previous Asian studies, inflammatory and ileo-colonic disease were the most common disease behavior and location ${ }^{(8,14,16,32,34)}$ in this cohort.

Though it is well-known fact that the IS, like thiopurines and 6- mercaptopurine are effective for both induction and maintenance of remission in $\mathrm{CD}^{(25)}$, only nearly two-thirds of patients in this cohort were treated with IS therapy for maintenance. The use of IS therapy in Asia varies between countries. A Korean single-centre study reported that thiopurines were used in only $63 \%$ of CD patients ${ }^{(44)}$. This phenomenon may relate to limited experience in managing $\mathrm{CD}$ and use of IS medications. In our study, while the male patients were more likely to be treated with the IS therapy once the diagnosis of CD was made, the female patients tended to be less frequently treated with the IS therapy and there was a considerable delay in prescription. This observation was in accord with the study from Blumenstein et al. who firstly observed that female was less frequently being treated with the IS therapy for $\mathrm{CD}^{(5)}$. There were two possible reasons behind these findings and they were as follows: a higher risk of getting more severe $\mathrm{CD}$ activity in males, and an avoidance of the use of IS therapy in females of child-bearing age. Further subgroup analysis in Blumenstein's study, that did not reveal any significant difference between women with and without child-bearing potential, did not support the latter mechanism $^{(5)}$. In our cohort, there were no significant differences in the clinical, including proportion that presented acutely and phenotypic characteristics of CD between men and women. Moreover, the median CDAI scores were similar (77 (IQR 48) vs 82 (IQR 67.3), $P=0.6$; data not shown) between men and women when the IS therapy was started. These observations did not support the former mechanism. On the other hand, more men were found to be treated with the IS therapy once the diagnosis of $\mathrm{CD}$ was made and the age-related analysis revealed women of child-bearing potential were significant less likely being treated with the IS therapy as compared with that of men. This observation suggested concern of the potential teratogenic side effect of IS agents would be the obstacle for women to commence with the IS therapy. Thiopurine, the most commonly used IS in CD, is reported to be of low risk during pregnancy ${ }^{(4,30,41)}$. But, the label of relative contraindication for peri-conceptional use of thiopurines is still pointed out by the pharmaceutical companies in the drug information sheet, which might be a barrier to patients with an active desire to conceive ${ }^{(3,6,10)}$. Conception plan is very important to consider in the management of CD. A recent study revealed that about one-third of patients had to adjust the treatment regimen during the management due to active reproductive plans ${ }^{(45)}$. Therefore, the clinicians should have a thorough discussion with the female patients on the effect of IS therapy and active disease activity on the risk of complications during pregnancy ${ }^{(14)}$.

Concerning use of biologic therapy, anti-TNF- $\alpha$ is shown to be effective at both induction and maintenance therapy in $\mathrm{CD}^{(25)}$. However, as with some Asian countries, use of antiTNF- $\alpha$ in both men and women of our cohort was low and this may be due to various factors including lack of clinician's experience, high treatment cost, lack of insurance reimbursement and concern about opportunistic infections ${ }^{(26)}$. In many Asian countries, the use of biologic therapy is self-financed, making the obstacle to their wider use.

Higher complication rate with a relative early onset in the male group might be related to higher frequency of smoking in men. Though there was relative more female patients having surgical intervention for CD, most of them $(90 \%)$ were performed with the objective of obtaining diagnostic information. Such a higher frequency of exploratory laparotomy of diagnostic purpose in the female group might be related to lower occurrence of GI symptoms and radiological abnormalities at presentation. We suggest clinicians should be aware of any extra-intestinal manifestation observed in patients in order to include $\mathrm{CD}$ as a potential diagnosis and consider less invasive investigation before any unnecessary exploratory laparotomy.

In our study, smoking and delay use of IS therapy were found to be significantly associated with complication development. Previous studies have demonstrated that cigarette smoking is an important environmental factor in CD that may lead to more complications and exacerbate its activity ${ }^{(5,17,18,34)}$. On the other hand, smoking cessation is associated with a $65 \%$ reduction in the risk of relapse as compared with active smoking, a similar magnitude of improvement to that obtained with IS therapy ${ }^{(17)}$. Though it is well-known fact that IS therapy are effective for both induction and maintenance of remission in $\mathrm{CD}^{(25)}$, Sung et al. found that most physicians in Asia favored the monotherapy of 5-Aminosalicylic acid medication as maintenance therapy of mild-to-moderate $\mathrm{CD}^{(36)}$. Besides the reasons that have been mentioned previously, another possible reason of avoiding using IS therapy might be the concern of its 
infective risk. In our cohort, there was considerable number of cases presented acutely. Few data are available to guide the decision regarding the optimal timing for starting IS therapy in newly-diagnosed $\mathrm{CD}$ if patients have potential septic complications. Previous published studies revealed that infection is a rare complication in patients with $\mathrm{CD}$ receiving IS therapy ${ }^{(1)}$ and thus we recommend early use of IS therapy should be considered once the septic issue is under-controlled because of its slow onset of action.

\section{ACKNOWLEDGEMENT}

We would like to thank Ms Annie LK Choi for proofreading our manuscript.

Law, ST, Li KK. Diferenças relativas aos sexos no curso clínico da doença de Crohn em uma população da Ásia: uma revisão de coorte retrospectivo. Arq Gastroenterol. 2014,51(2):90-6.

RESUMO - Contexto - Os dados de populações asiáticas sobre as diferenças de gênero em doença de Crohn são poucos. Objetivo - Este estudo analisou as características clínicas entre mulheres e homens afetados pela doença de Crohn. Métodos - Estudo ininterrupto de coorte retrospectivo para analisar pacientes com doença de Crohn a partir de janeiro de 2000 a dezembro de 2012. Foram avaliadas as características clínicas e fenotípicas e os resultados do tratamento. Resultados - Foram diagnosticados 79 pacientes (55 do sexo masculino, sendo 2 deles com história familiar positiva). A lesão inflamatória e a localização ileocolônica foram a apresentação mais comum para ambos os sexos. Além da alta frequência de náusea (45,83\% vs $23,64 \%, P=0,024)$ e baixo índice de massa corporal $\left(19,44 \mathrm{vs} 22,03 \mathrm{~kg} / \mathrm{m}^{2}, P=0,003\right)$ relatado em mulheres, há diferenças significativas relacionadas com o gênero nas características clínicas observadas. As mulheres foram mais associadas com o uso tardio de terapia com imunossupressor (12 vs 36 meses, $P=0,028)$, especialmente para aquelas com idade inferior à 40 anos $(85 \%$ vs $62,6 \%, P=0,023)$. A análise de regressão de riscos proporcionais de Cox revelou que o tabagismo ativo (taxa de risco 4,679, intervalo de confiança de 95\%,1,03-21,18) e uso de terapia imunossupressora (taxa de risco 4,13, 95\% e intervalo de confiança, 1,01-16,88) foram fatores de risco independentes associados ao aumento do risco de complicações. Conclusões Não houve diferenças significativas específicas de gêneros masculinos e femininos nas características clínicas e fenotípicas nos pacientes com doença de Crohn. História de tabagismo e uso tardio da terapia imunossupressora foram associados com maior risco de complicações.

DESCRITORES - Doença de Crohn. Identidade de gênero. Imunossupressores, uso terapêutico. Hábito de Fumar. 


\section{REFERENCES}

1. Aberra FN, Lichtenstein GR. Methods to avoid infections in patients with inflammatory bowel disease. Inflamm Bowel Dis. 2005;11:685-95.

2. Asakura K, Nishiwaki Y, Inoue N, Hibi T, Watanabe M, Takebayashi T. Prevalence of ulcerative colitis and Crohn's disease in Japan. J Gastroenterol. 2009;44:659-65.

3. Baars JE, Zelinkova Z, Mensink PB, Markus T, Looman CW, Kuipers EJ, et al High therapy adherence but substantial limitations to daily activities amongst members of the Dutch inflammatory bowel disease patients' organization: a patient empowerment study. Aliment Pharmacol Ther. 2009;8:864-72

4. Bermas BL, Hill JA. Effects of immunosuppressive drugs during pregnancy. Arthritis Rheum. 1995; 12:1722-32.

5. Blumenstein I, Herrmann E, Filmann N, Zosel C, Tacke W, Bock H, et al. Female patients suffering from inflammatory bowel diseases are treated less frequently with immunosuppressive medication and have a higher disease activity: a subgroup analysis of a large multi-centre, prospective, internet-based study. J Crohns Colitis. 2011;5:203-10.

6. Bokemeyer B, Teml A, Roggel C, Hartmann P, Fischer C, Schaeffeler E, et al. Adherence to thiopurine treatment in out-patients with Crohn's disease. Aliment Pharmacol Ther. 2007;2:217-25

7. Calkins BM, Mendeloff AI. The epidemiology of idiopathic inflammatory bowel disease. In: Kirsner JB, Shorter RG, eds. Inflammatory bowel disease, 4th ed. Baltimore: Williams \& Wilkins. 1995:31- 68

8. Chow DK, Leong RW, Lai LH, Wong GL, Leung WK, Chan FK, Sung JJ. Changes in Crohn's disease phenotype over time in the Chinese population: validation of the Montreal classification system. Inflamm Bowel Dis. 2008;14:536-41.

9. Das K, Ghoshal UC, Dhali GK, Benjamin J, Ahuja V, Makharia GK. Crohn's disease in India: a multicenter study from a country where tuberculosis is endemic. Dig Dis Sci. 2009;54:1099-107.

10. Ediger JP, Walker JR, Graff L, Lix L, Clara I, Rawsthorne P, et al. Predictors of medication adherence in inflammatory bowel disease. Am J Gastroenterol. 2007; 7:1417-26.

11. Farmer RG, Whelan G, Fazio VW. Long-term follow-up of patients with Crohn's disease. Relationship between the clinical pattern and prognosis. Gastroenterology. 1985;88:1818-25.

12. Farrokhyar F, Swarbrick ET, Irvine EJ. A critical review of epidemiological studies in inflammatory bowel disease. Scand J Gastroenterol. 2001;36:2-15. Erratum in: Scand J Gastroenterol. 2001;36:facing 561.

13. Greenstein AJ, Janowitz HD, Sachar DB. The extra-intestinal complications of Crohn's disease and ulcerative colitis: A study of 700 patients. Medicine. 1976;55:404-12.

14. Heetun ZS, Byrnes C, Neary P, O'Morain C. Review article: reproduction in the patient with inflammatory bowel disease. Aliment Pharmacol Ther. 2007;4:513-33.

15. Ishige T, Tomomasa T, Takebayashi T Asakura K, Watanabe M, Suzuki T, et al. Inflammatory bowel disease in children: epidemiological analysis of the nationwide IBD registry in Japan. J Gastroenterol. 2010;45:911-7.

16. Jiang L, Xia B, Li J, Ye M, Yan W, Deng C, et al. Retrospective survey of 452 patients with inflammatory bowel disease in Wuhan city, central China. Inflamm Bowel Dis. 2006;12:212-7.

17. Johnson GJ, Cosnes J, Mansfield JC. Review article: smoking cessation as primary therapy to modify the course of Crohn's disease. Aliment Pharmacol Ther. 2005;21:921e31.

18. Kane SV, Flicker M, Katz-Nelson F. Tobacco use is associated with accelerated clinical recurrence of Crohn's disease after surgically induced remission. J Clin Gastroenterol. 2005;39:32-5.

19. Kyle J. Crohn's disease in the northeastern and northern isles of Scotland: An epidemiological review. Gastroenterology. 1992;103:392-9.

20. Latour P, Belaiche J, Louis E, Fontaine F, Deflandre J, Loly J, et al. Incidence of inflammatory bowel disease in the province of Liège (Belgium). Acta Gastroentero Belg. 1996;59:3-6.

21. Lee YM, Fock K, See SJ. Racial differences in the prevalence of ulcerative colitis and Crohn's disease in Singapore. J Gastroenterol. Hepatol. 2000;15:622-5.

22. Lennard-Jones JE. Classification of inflammatory bowel disease. Scand J Gastroenterol Suppl. 1989;170:2-6.

23. Loftus EV Jr, Schoenfeld P, Sandborn WJ. The epidemiology and natural history of Crohn's disease in population-based patient cohorts from North America: a systematic review. Aliment Pharmacol Ther. 2002;16:51-60.
24. Luo CH, Wexner SD, Liu QS, Li L, Weiss E, Zhao RH. The differences between American and Chinese patients with Crohn's disease. Colorectal Dis. 2011;13:166-70.

25. Mowat C, Cole A, Windsor A, Ahmad T, Arnott I, Driscoll R, et al. Guidelines for the management of inflammatory bowel disease in adults. Gut. 2011;60:571-607.

26. Ooi CJ, Fock KM, Makharia GK, Goh KL, Ling KL, Hilmi I. The Asia-Pacific consensus on ulcerative colitis. J Gastroenterol. Hepatol. 2010;25:453-68.

27. Oriuchi T, Hiwatashi N, Kinouchi Y. Clinical course and longterm prognosis of Japanese patients with Crohn's disease: predictive factors, rates of operation, and mortality. J Gastroenterol. 2003;38:942-53.

28. Prideaux L, Kamm MA, De Cruz PP, Chan FK, Ng SC. Inflammatory bowel disease in Asia: a systematic review. J Gastroenterol Hepatol. 2012;27:1266-80.

29. Rankin GB, Watts HD, Melnyk CS, Kelley ML Jr. The national cooperative Crohn's disease study: Extraintestinal manifestations and perianal complications. Gastroenterology. 1979;77:914-20.

30. Roubenoff R, Hoyt J, Petri M, Hochberg MC, Hellmann DB. Effects of antiinflammatory and immunosuppressive drugs on pregnancy and fertility. Semin Arthritis Rheum. 1988;2:88-110.

31. Satsangi J, Silverberg MS, Vermeire S, Colombel JF. The Montreal classification of inflammatory bowel disease: controversies, consensus, and implications. Gut. 2006;55:749-53.

32. Shin DH, Sinn DH, Kim YH, Kim JY, Chang DK, Kim EJ, et al. Increasing incidence of inflammatory bowel disease among young men in Korea between 2003 and 2008. Dig Dis Sci. 2011;56:1154-9.

33. Shivananda S, Peña AS, Nap M, Weterman IT, Mayberry JF, Ruitenberg EJ, Hoedemaeker PJ. Epidemiology of Crohn's disease in region Leiden, the Netherlands. A population study from 1979 to 1983. Gastroenterology. 1987;93:966-74

34. Song XM, Gao X, Li MZ, Chen ZH, Chen SC, Hu PJ, et al Clinical features and risk factors for primary surgery in 205 patients with Crohn's disease: analysis of a South China cohort. Dis Colon Rectum. 2011;54:1147-54.

35. Subasinghe D, Nawarathna NM, Samarasekera DN. Disease characteristics of Inflammatory Bowel Disease (IBD): findings from a Tertiary Care Centre in South Asia. J Gastrointest. Surg. 2011;15:1562-7.

36. Sung JJ, Kamm MA, Marteau P. Asian perspectives in the management of in flammatory bowel disease: findings from a recent survey. J Gastroenterol Hepatol. 2010;25:183-93.

37. Van Gossum A, Adler M, De Reuck M, Devis G, Fiasse R, Vanheurverzwijn R, Willocx R. Epidemiology of inflammatory bowel disease in Brussels' area (19921993). Acta Gastroenterol Belg. 1996;59:7-9.

38. Vavricka SR, Brun L, Ballabeni P, Pittet V, Prinz Vavricka BM, Zeitz J, Rogler G, et al. Schoepfer AM. Frequency and risk factors for extraintestinal manifestations in the Swiss inflammatory bowel disease cohort. Am J Gastroenterol. 2011;106:110-9.

39. Wagtmans MJ, Verspaget HW, Lamers CB, van Hogezand RA. Gender-relat ed differences in the clinical course of Crohn's disease. Am J Gastroenterol. 2001;96:1541-6.

40. Whelan G. Epidemiology of inflammatory bowel disease. Med Clin North Am 1990;74:1-12.

41. Willis FR, Findlay CA, Gorrie MJ, Watson MA, Wilkinson AG, Beattie TJ. Children of renal transplant recipient mothers. Children of renal transplant recipient mothers. J Paediatr Child Health. 2000;3:230-5

42. Yang SK, Yun S, Kim JH, Park JY, Kim HY, Kim YH, et al. Epidemiology of inflammatory bowel disease in the Songpa-Kangdong district, Seoul, Korea, 1986-2005: a KASID study. Inflamm Bowel Dis. 2008;14:542-9.

43. Yao T, Matsui T, Hiwatashi N. Crohn's disease in Japan: diagnostic criteria and epidemiology. Dis. Colon Rectum. 2000;43:S85-93.

44. Ye BD, Yang SK, Cho YK, Park SH, Yang DH, Yoon SM, et al. Clinical features and long-term prognosis of Crohn's disease in Korea. Scand. J Gastroenterol. 2010;45:1178-85

45. Zelinkova Z, Mensink PB, Dees J, Kuipers EJ, van der Woude CJ. Reproductive wish represents an important factor influencing therapeutic strategy in inflammatory bowel diseases. Scand J Gastroenterol. 2010;1:46-50.

46. Zheng JJ, Zhu XS, Huangfu Z, Shi XH, Guo ZR. Prevalence and incidence rate of Crohn's disease in mainland China: a meta-analysis of 55 years of research. J Dig Dis. 2010;11:161-6.

Received 11/8/2013 Accepted 4/12/2013 